\title{
Empirical Investigation of Healthcare Financing and Its Influence on Social Security: Peculiarities, Problems and Challenges
}

\author{
George Abuselidze ${ }^{1, *}$ \\ ${ }^{1}$ Batumi Shota Rustaveli State University, Georgia
}

\begin{abstract}
The global pandemic has posed significant challenges to the healthcare system. Ensuring social security has become an important concern of the government. The aim of the paper is to determine the relevance of public spending on health. Also, is there any standard measurement or recommendation of how much the government should spend or not, even considering the economic situation of the country? This led to the study of the experiences of different countries in this regard. The crisis caused by the epidemic most likely involves a longer period of time than COVID-19 itself. Accordingly, the results presented in the study and the recommendations developed based on it have practical implications for the link between crisis elimination, health and well-being.
\end{abstract}

\section{Introduction}

During the pandemic, certain types of financial and economic mechanisms were implemented for social security in a global world. During Covid-19 it became necessary to implement some kind of social policy by the government to help individuals and legal entities in a state of emergency.

In parallel with the spread of the pandemic, the countries (the governments of Georgia, Ukraine, Azerbaijan, Turkey, Russia and the Baltic States) began to take action to protect the social security of citizens [1]. In particular, the medical expenses of those infected with the virus are financed by the government. There are also special quarantine zones in hotels, where citizens are provided with food and basic necessities and a doctor's consultation completely free of charge.

So during the pandemic each country tries to take measures to prevent the virus and improve social welfare. By raising additional funds they help to reduce the number of infected people to a minimum and take care of the population.

Social protection of the population is one of the most important components of the country's social relations and social policy. Its purpose is to provide basic living and working conditions for the people: to provide materially for the population and to organize social and medical care for the disabled members of the community.

The budget as the financial basis for the functioning of the country and the sustainable development of the economy is closely linked to social policy. The government through the budget influences the social and economic development of the country, the financing of targeted programs of economic and social nature, the balance of social and intersectoral processes, the achievements of scientific and technological progress, the country's economic growth and macroeconomic stability [2-6].

\section{Methodological foundations}

\subsection{Research Methodology}

The research methodology is based on a) McKibbin \& Sidorenko (2006) [7]; The model of Global macroeconomic consequences of pandemic influenza described in the study, which can determine the impact of the epidemic on the scale of global economic crises and GDP decline [7, 8]; b) The 2016 model presented by economists from the National Bureau of Economic Research (Fan, V. Y; Jamison, D. T; Summers, L. H) [9] based on an analysis of all cases of epidemics from the 18 th century to the present and ranked with each other the scale of the related epidemic and the decline in revenue.

It is noteworthy that events in developing and developed countries can develop in different scenarios. Therefore, this study uses multifactorial models and evaluates the effectiveness of health financing and its impact on economic growth based on empirical research.

\subsection{Literature Review}

If we think about what human well-being depends on, what influences it positively or negatively and analyze the lives of the rich and the poor, we will make sure that there are requirements without them it is impossible to exist. But at the same time there are demands without which prosperity is impossible. The list of these requirements is

\footnotetext{
* Corresponding author: george.abuselidze@bsu.edu.ge
} 
different because different scientists develop different views.

According to Blank and Burau [10], approaches to health financing were initially based on a minimum public contribution, when private contributions should be the mainstay. Different countries use different approaches Adinma \& Adinma, 2010; Behera \& Dash, 2020; Cai, et al., 2020; Eriksen, \& Wiese, 2019; Farughi, et al., 2019; Ivanková, et al., 2020; Kwon, 2003; Loganathan, et al., 2020; Manchanda, 2020; Oraro-Lawrence \& Wyss, 2020; Riman \& Akpan, 2012; Rokicki, et al., 2021; Rostampour \& Nosratnejad, 2020; Vakulenko, et al., 2020; Wong, et al., 2020; T. Z. Moghadam, et al., 2019; N. Ojong, 2019 [11-28]. For example, the New Zealand system seems theoretically universal. However, in practical terms, access to first aid is difficult for poor people, because of the first aid system is based on out-of-pocket payments by consumers, while the second aid system is based on a single taxation system. This system can be contrasted with mixed types of systems - government insurance (60\% for less affluent citizens) and private insurance (40\% for more affluent citizens). For example, in the Netherlands, where the primary healthcare system is freely used by those who are insured by the government, Although the given system exists in parallel with the private insurance market [29, 30]. In addition to these systems, it is possible for the government to fund certain health services for specific segments of the population, while other parts of the system may be based on private insurance (for example, the US Medicaid Medical Program).

It seems that the public health sector is the exclusive sponsor of all major services and this is reimbursed from tax revenues. In addition, the government can provide healthcare funding to more private or non-profit organizations. An example of this is Canada where local governments pay health service bills through common taxation.

In the case of government funded insurance schemes, the government requires individuals and sometimes employers to contribute to insurance and this is mainly done through salaries. For example, the multi-component system in Germany and France is based on this type of insurance, often referred to as the Bismarck system [31, $32]$.

\section{Results and Discussion}

The amount of public spending on financing the healthcare system is determined by the values, priorities, political will and level of economic development of the country, budget opportunities and other factors. Some scholars believe that the increase in public spending on health is a heavy burden on the already small budget of the country. So this kind of social orientation of the budget reduces capital expenditures, which hinders economic growth in the country. Consequently, in some countries, healthcare is not considered a budget policy priority for financial and political reasons. In particular, some governments view healthcare as an economically inefficient sector. In contrast, the governments of some countries are interested in having a healthy population.

Every year, the cost of healthcare by the government is increasing in developed countries. In such countries, the healthcare system is based on the principle of public solidarity and most of the healthcare costs are paid by the government through health programs or social insurance systems. In many countries, the larger the gross domestic product, the greater the government's share of healthcare funding. In many countries, the larger the gross domestic product, the greater the government's share of health are funding.

It is clear from the comparative analysis of the indicators of the evaluation of the health financing system developed by the World Health Organization, as well as the statistical data of other countries (both developed and developing), that despite the increase in public spending on health, Georgia still lags behind not only the international standards set by the World Health Organization, but also the rates of many low-income countries. Accordingly, in order to evaluate health financing in Georgia, the article discusses the following internationally recognized indicators of the effectiveness of the health financing system:

* Proportion of government expenditures on healthcare in the total government expenditures;

* Proportion of public expenditures on healthcare in total health expenditures;

* Government spending on healthcare in relation to GDP;

* Total expenditures on healthcare in relation to GDP;

* Private spending on healthcare.

\subsection{Proportion of Government expenditures on healthcare in the total expenditures}

One of the most important values of any country is human health, which is significantly influenced by the obligations of the government in the field of healthcare. What importance it attaches to the health sector can be seen in the government expenditures and the share of health in the total government expenditures shows the country's attitude towards the health sector. Government commitments to healthcare should increase as national revenues increase. However, some low-income countries allocate more government funds to healthcare than highincome countries [33]. According to current data, public spending on health in 22 low-income countries accounted for more than $10 \%$ of the budget, while in 11 high-income countries less than $10 \%$ of the budget was spent (World Health Report 2020). According to research, the main source of healthcare spending in the world is government funding - $35 \%$, compulsory social insurance - $27 \%$, outof-pocket payments and private insurance contributions $38 \%$ [34]. According to the World Health Organization, the share of public spending on total public health spending should be at least 15\% [35] (see Figure 1). 


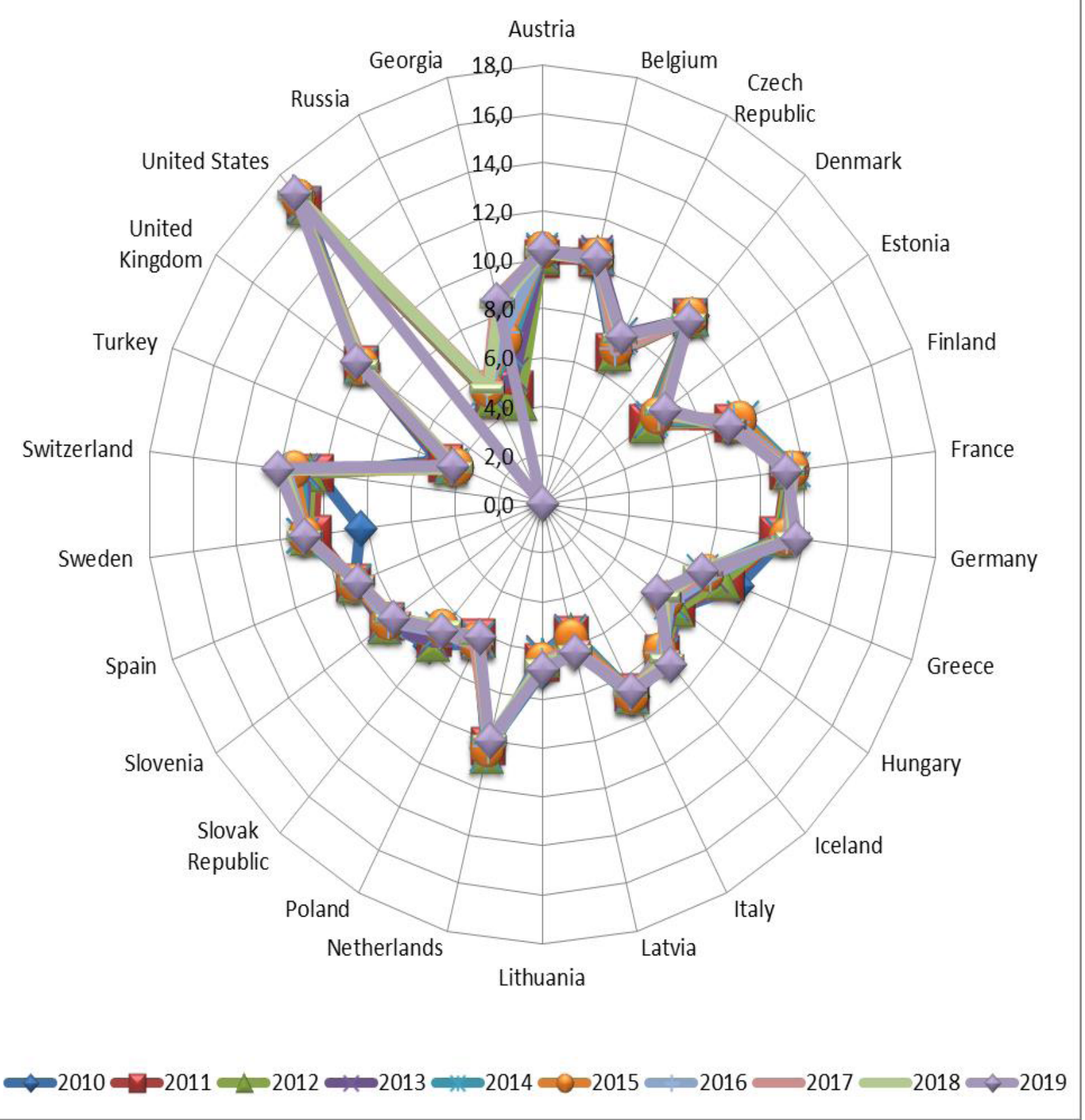

Fig. 1. The public spending on healthcare

Source: compiled on the basis of research by the author

The share of public spending on healthcare in the European region ranges from $4 \%$ to almost $20 \%$ of total public spending [33]. Despite the significant increase in public spending on health, its share of the budget in Georgia is quite low at $8.6 \%$. This is almost twice as small as the data provided by the World Health Organization. The share of public expenditures on healthcare in Georgia in total public expenditures is low compared to countries such as: Armenia (7.9\%), Kazakhstan (10.9\%), Ukraine (12.2\%), Kyrgyzstan (13.2\%), Belarus (13.5\%).

\subsection{Proportion of public expenditures on healthcare in total health expenditures}

Total expenditures on healthcare include both public and private expenditures. In some countries, the provision of health services is based on the private sector. Even in explicitly publicly funded systems, public actors and governments work with the private sector to at least procure medical equipment. Increasingly, governmentprivate partnerships extend to the provision of infrastructure, additional equipment, medical care and etc. [36].

According to the World Health Organization, public health expenditures should account for more than $40 \%$ of total health expenditures (see Figure 2).

\footnotetext{
* Corresponding author: george.abuselidze@bsu.edu.ge
} 


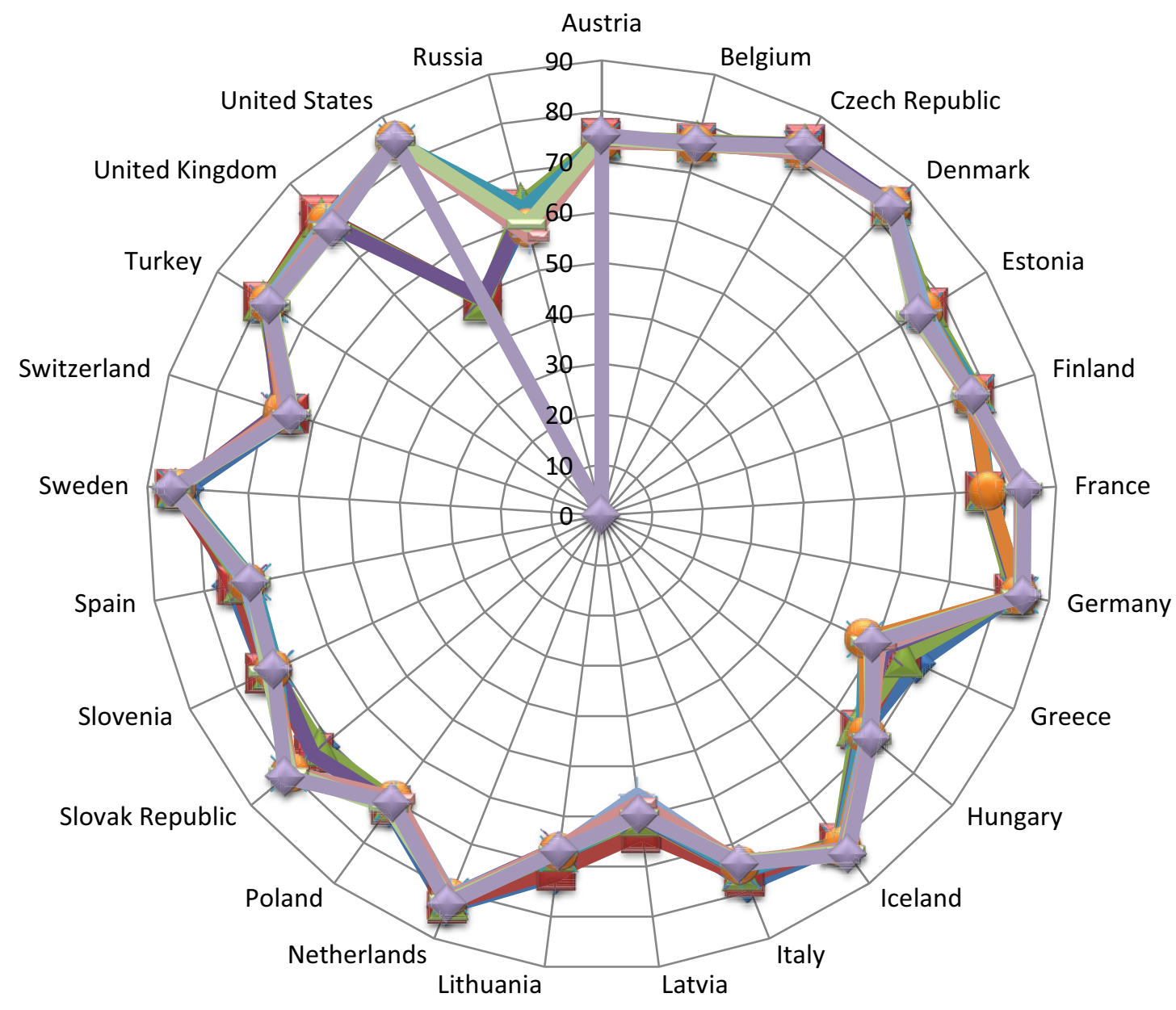

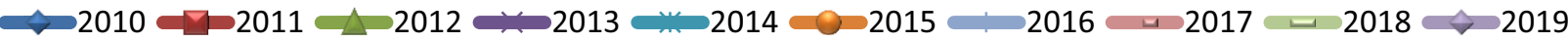

Fig. 2. Government / compulsory schemes Current expenditure health Source: Compiled on the basis of research by the author [37, 38]

In countries where the rate is less than $40 \%$, the government has a limited responsibility to address problems in the healthcare sector. This limit was exceeded by post-Soviet countries such as Armenia (41.7\%), Kazakhstan (53.1\%), Ukraine (54.5\%) and Kyrgyzstan (59\%). Public spending on healthcare in Georgia is $29.8 \%$, therefore, the share of government funding is significantly below the threshold set by the 3.3 Government spending on healthcare (GDP, $\%)$

According to the World Health Organization, the share of public spending on health should be not less than $5 \%$ of GDP (see Figure 3). recommendation of the World Health Organization.

\footnotetext{
* Corresponding author: george.abuselidze@bsu.edu.ge
} 


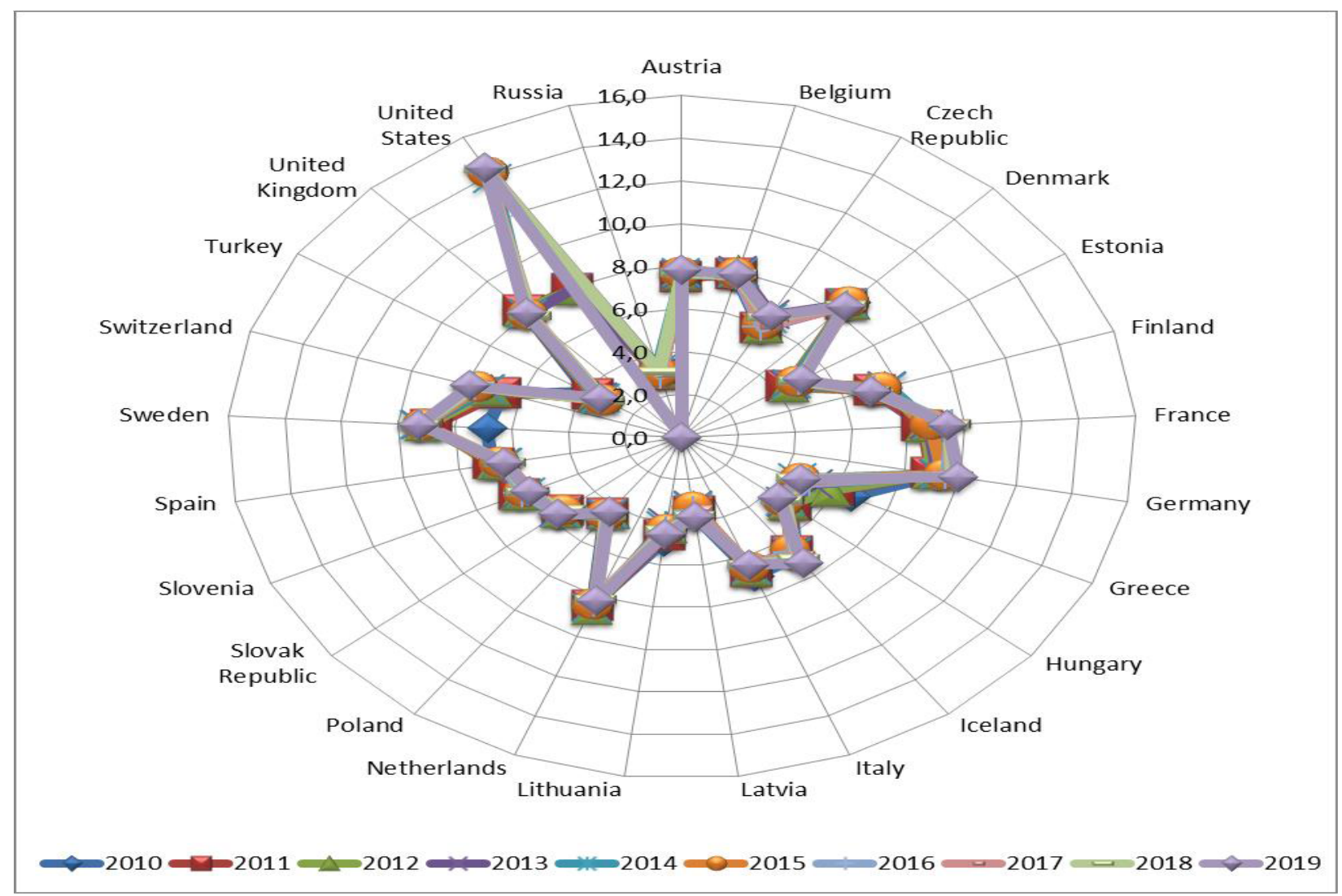

Fig 3: government / compulsory schemes Current health expenditure (\%, of GDP) 2010-2019

Source: Compiled on the basis of research by the author [37, 38]

The situation in the post-Soviet countries is not so good in this respect. In particular, Kazakhstan $(2.3 \%)$, Kyrgyzstan (3.9\%), Belarus (4\%), Ukraine (4.2\%), Georgia (2.2\%).

\subsection{Total expenditures on health (GDP, \%)}

The best measure of public welfare is the share of total expenditures on health (GDP, \%). It ranges from 1 to $17 \%$ in different countries. With this indicator, the share of total expenditures on healthcare in relation to GDP is equal to the indicators of the countries of the European region.

All of the above indicates that a significant share of healthcare expenditures in Georgia $(65-70 \%)$ is private expenditures incurred by the population, which indicates that healthcare in Georgia is not considered a priority of the government policy.

With such a high share of private spending on total health expenditures, Georgia ranks eighth in the world (Sudan 75.8\%, Yemen 74\%, Afghanistan 73.8\%, Azerbaijan $71.1 \%$, Nigeria $69.3 \%$, Myanmar 68.2\%, Venezuela $65.8 \%$ ). It means that many families in Georgia are forced to refuse the necessary medical services because they cannot pay for these services.

Studies show that the higher the cost of healthcare the more accessible medical care is the higher the health status of the population [34]. The data show that there is a big difference between the health of the population of a rich and a poor country and this difference can lead to a difference in income between countries.

\subsection{Modeling health and income interactions}

To consider health and income as endogenous variables and the horizontal axis shows the per capita income (x) but the vertical axis - human health (y). The curve y (x) represents the impact of per capita income on health (Figure 4).

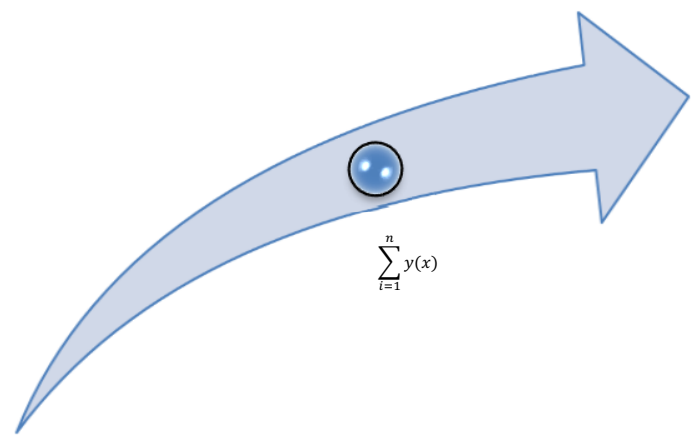

Fig. 4. The impact of income on health Source: Compiled by the author

As we can see the curve is upward and shows that income growth improves health (see Curve 4), however, after a certain period the more the income curve increases the more it becomes horizontally adjusted. This suggests that the positive effects of income on health care are clearer in the case of low income levels. While the curve $\mathrm{x}(\mathrm{y})$ shows the impact of health on income per capita. The

\footnotetext{
* Corresponding author: george.abuselidze@bsu.edu.ge
} 
lower the $\mathrm{x}$ value the less products can be produced (Figure 5).

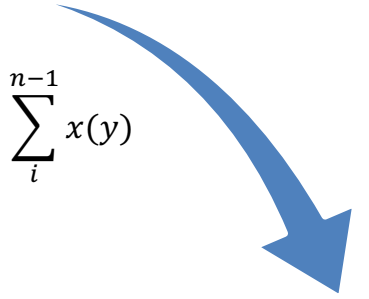

Fig. 5. The impact of health on income Source: Compiled by the author

It should be noted, that income differences across countries can be explained by №4 and №5 figures. It is a matter of discussion which opinion is more important: an opinion that describes the effects of poor health on the level of poverty in a country or a vision that describes the differences in health in rich and poor countries, which is maintained despite the same levels of per capita income.
Much of the correlation between health status and per capita income is due to people in richer countries devoting more resources to health. But differences in health may be due to factors other than income, such as the country's health environment.

In analysis of the relationship between income and health found that if the countries differ in their healthcare environment, this difference will affect both income and actual health.

$$
\begin{array}{r}
Y_{i}=\beta+\beta_{1} \text { per capita } \text { income }_{1}+\beta_{2} \text { health } \text { funding }_{2} \\
+\cdots \beta_{k} \text { health environment } \\
+\widehat{u}_{\imath}
\end{array}
$$

The global pandemic has made it clear to us the need to increase healthcare funding. However, increasing public spending on healthcare should not become a major goal of health financing policy. An increase in government funding can only be justified if the resources available to the health system are used effectively. Countries that use health funding resources effectively to successfully accomplish health system objectives have relatively low mortality rates there (see Figure 6).

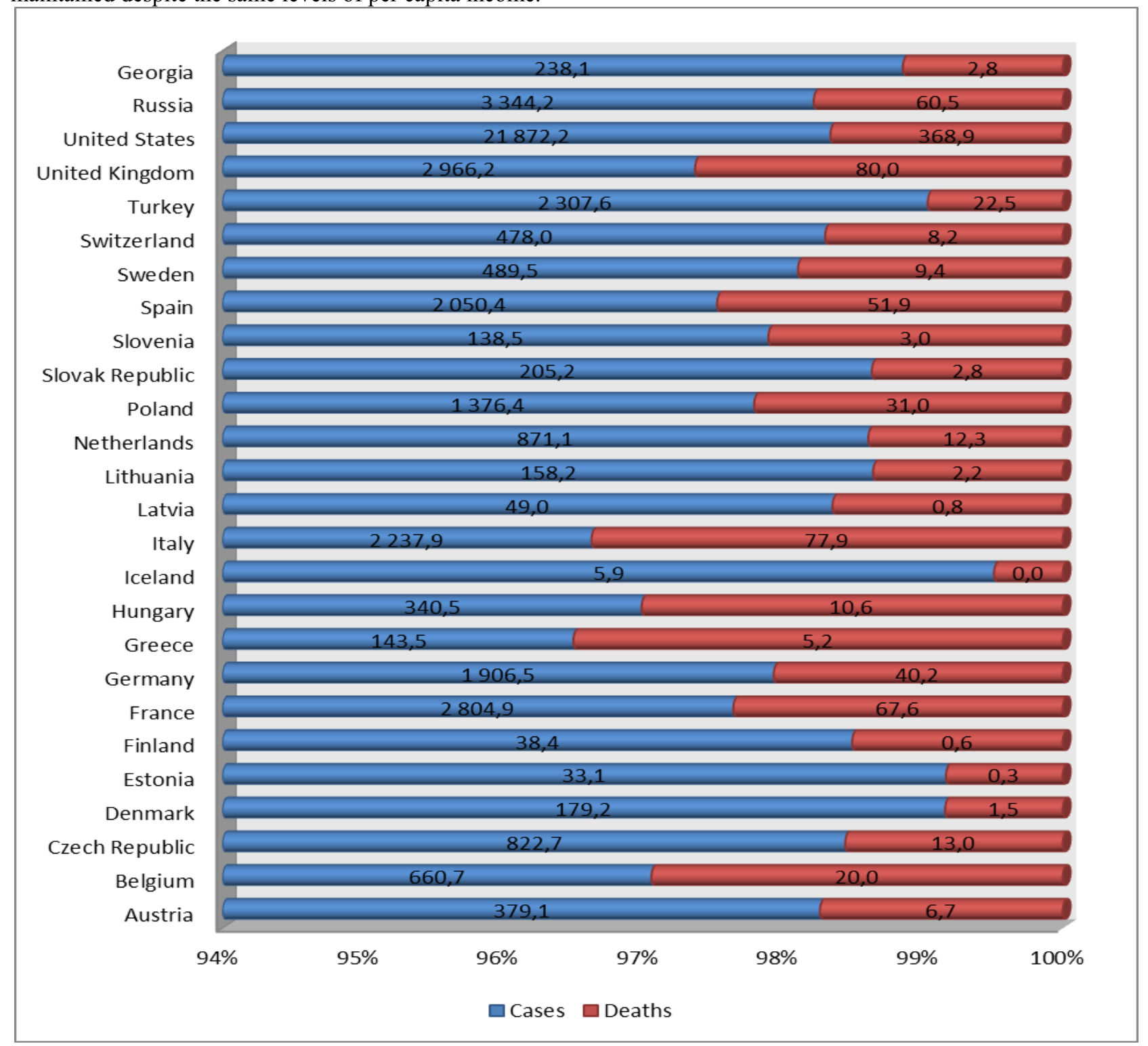


Fig. 4. COVID-19 dashboard 2020-2021 (Thousand people) Source: Compiled on the basis of research by the author

Therefore, the difference in the healthcare environment between countries is subject to the multiplier effect: countries with better health environments will have healthier workers who produce more products, which provides better nutrition and medical care, which in turn improves health.

\section{Conclusions}

The study makes it clear that every government cares about protecting and improving the health of its own population. Many different methods are used to fund the achievement of these goals. On the one hand, governments use their power over financial resources to cover healthcare costs with tax revenues, on the other hand, some countries waive a fairly large portion of taxes to encourage individuals to apply health insurance policies. The paper shows the differences in the financing of healthcare systems in different countries, which is due to the different views of the authorities on the role and importance of healthcare funding growth. Governments in different countries are also using their power successfully and requiring individuals to engage in health insurance to protect and promote their own health.

The results of the study developed a model for the interaction between health, which explains the link between health and income. It has been suggested that the government should increase funding for healthcare in proportion to GDP growth in order to better protect the health of individuals and as a result production will be able to generate even more value added. Consequently, countries will be more flexible during global pandemics. The economy will be protected from dependence on health and welfare growth will be sustainable.

\section{References}

1. G. Abuselidze, A. Slobodianyk, Social responsibility of business and government in the conditions of the COVID-19 pandemic, E3S Web of Conferences 210, 15016 (2020) doi:10.1051/e3sconf/202021015016

2. G. Abuselidze, L. Mamaladze, The Impact of the COVID-19 Outbreak on the Socio-Economic Issues of the Black Sea Region Countries, Lecture Notes in Computer Science 12253, 453467 (Springer, Cham 2020) doi:10.1007/978-3030-58814-4_32

3. G. Abuselidze, A. Slobodianyk, Pandeconomic Crisis and Its Impact on Small Open Economies: A Case Study of COVID-19, Advances in Intelligent Systems and Computing 1258, 718728 (Springer, Cham 2021) doi:10.1007/978-3030-57450-5_61

4. G. Abuselidze, The Influence of Covid-19 on the Public Debt Growth and Default Risk: A Fiscal Sustainability Analysis, in Proceedings of the
International Scientific and Practical Conference on Sustainable Development of Regional Infrastructure - ISSDRI, 151-159 (SciTePress, 2021) doi:10.5220/0010587501510159

5. G. Abuselidze, L. Mamuladze, The Peculiarities of the Budgetary Policy of Georgia and the Directions of Improvement in Association with EU, SHS Web of Conferences 73, 01001 (2020). doi:10.1051/shsconf/20207301001

6. G. Abuselidze, M. Surmanidze, Analysis of Performance Efficiency of Legal Entities of Public Law and Non-Profit Legal Entities under the Central and Local Government Bodies: in Terms of the Transformation of Georgia with the EU, in Proceedings of the 5th International Conference on European Integration 2020, 23-35 (2020) doi:10.31490/9788024844565

7. W. J. McKibbin, A. A. Sidorenko, Centre for Applied Macroeconomic Analysis Global Macroeconomic Consequences of, The Crawford School of Public Policy (2006)

8. Center for Systems Science and Engineering (CSSE) at Johns Hopkins University (JHU). COVID-19 Dashboard 2020-2021. https://www.arcgis.com/apps/opsdashboard/ind ex.html?fbclid=IwAR2wleBKc6HgVg4updq96jsHS Zjowozz5z18B9umJ1s2tGTTTSDDINNS2Xk\#/bda 7594740fd40299423467b48e9ecf6

9. V. Y. Fan, D. T. Jamison, L. H. Summers, The inclusive cost of pandemic influenza risk, National Bureau of Economic Research, No. w22137 (2016)

10. R. H. Blank, V. Burau, Comparative Health Policy (Basingstoke: Palgrave Macmillan, 2004)

11. E. D. Adinma, B.D.J. Adinma, Nigerian Medical Journal 51(3), 95-100 (2010)

12. D. K. Behera, U. Dash, International Journal of Healthcare Management 13(sup1), 375-384 (2020) doi:10.1080/20479700.2018.1548159

13. C. Cai, J. Runte, I. Ostrer, K. Berry, N. Ponce, M. Rodriguez, ... J. G. Kahn, PLoS medicine 17(1), e1003013 doi:10.1371/journal.pmed.1003013

14. S. Eriksen, R. Wiese, European Journal of Political Economy 59, 71-82 (2019) doi:10.1016/j.ejpoleco.2019.02.001

15. H. Farughi, S. Mostafayi, J. Arkat, Journal of Optimization in Industrial Engineering 12(1), 119-131 doi:10.22094/JOIE.2018.766.1489

16. V. Ivanková, M. Rigelský, R. Kotulič, J. Gonos, Polish Journal of Management Studies 21(2), 179-194 doi:10.17512/pjms.2020.21.2.13

\footnotetext{
* Corresponding author: george.abuselidze@bsu.edu.ge
} 
17. S. Kwon, International Social Security Review 56(1)， 75-94 (2003) doi:10.1111/1468246X.00150

18. T. Loganathan, Z. X. Chan, N. S. Pocock, PLoS One 15(12), e0243629 (2020) doi:10.1371/journal.pone.0243629

19. N. Manchanda, The European Journal of Development Research, 1-39 (2020) doi:10.1057/s41287-020-00312-w

20. T. Oraro-Lawrence, K. Wyss, BMC health services research 20(1), 1-11 (2020) doi:10.1186/s12913-020-5041-x

21. H. B. Riman, E. S. Akpan, International Journal of Humanities and Social Science 2(15), 296309 (2012)

22. T. Rokicki, A. Perkowska, M. Ratajczak, Sustainability 13(1), $251 \quad$ (2021) doi:10.3390/su13010251

23. M. Rostampour, S. Nosratnejad, Value in health regional issues 21, $133-140 \quad$ (2020) doi:10.1016/j.vhri.2019.10.001

24. V. Vakulenko, A. Bourmistrov, G. Grossi, International Journal of Public Sector Management 33(5), 519-534 (2020) doi:10.1108/IJPSM-10-2019-0262

25. A. Wong, S.N. Goh, P.M. Sowa, J.D. Bauer, Health Policy 124(10), 1146-1154 (2020) doi:10.1016/j.healthpol.2020.06.008

26. T. Z. Moghadam, P. Raeissi, M. Jafari-Sirizi, International Journal of Human Rights in Healthcare 12(2), 124-137 (2019) doi:10.1108/IJHRH-07-2018-0044

27. N. Ojong, Societies 9(4), 77 (2019) doi:10.3390/soc9040077

28. G. Yamey, M. Schäferhoff, O. K. Aars, B. Bloom, D. Carroll, M. Chawla, ... E. Whiting, The Lancet Global Health 5(8), e742-e744 (2017) doi:10.1016/S2214-109X(17)30203-6

29. G. Yamey, D. Jamison, O. Hanssen, A. Soucat, Health Systems \& Reform 5(4), 334-349 (2019) doi:10.1080/23288604.2019.1663118

30. C. M. Flood, International Health Care Reform: $A$ Legal, Economic and Political Analysis (London: Routledge, 2000)

31. J. S. Hacker, British Journal of Political Science 34(4), 693-724 (2004)

32. A. M. Yemane, H. A. Heniey, K. G. Gebrehiwet, Journal of Optimization in Industrial Engineering 14(2), 57-67 doi:10.22094/JOIE.2020.1870857.1662

(2021)

33. World Health Report, Health Systems Financing: the Path to Universal Coverage (World Health Organization, 2020)
34. Th. Getzen, Health Economics and Financing, in 5th Edition (Wiley, 2012)

35. Organisation of African Unity, African Summit on HIV/AIDS, tuberculosis and other related infectious diseases. Abuja Declaration on HIV/AIDS, Tuberculosis and Other Related Infectious Diseases, 24-27 April 2001

36. P. Alcock, G. Craig, International Social Policy: Welfare Regimes in the Developed World, 2nd edn., 1-24. (Basinstoke: Plgrave Macmillan, 2009)

37. OECD. Health Status 2010-2020 (2021). https://stats.oecd.org/Index.aspx?DatasetCode= HEALTH_STAT

38. The World Bank. Health expenditure, public (\% of GDP). (World Bank Open Data, 2015) 